\title{
A retomada da tese de Trasímaco no segundo livro de A República
}

\author{
Roberto Bolzani Filho
}

This text intends to analyse the new version of Trasymachus' thesis proposed by Glaucon and Adimantus in Republic II. Its aim is to understand its philosophical intentions and main aspects. We attempt to show that there is an important methodological change, related to a new terminology adopted to express Trasymachus' thesis, and, most significantly, a new attitude of both interlocutors, especially Glaucon, towards the investigation, as we now find interlocutors presenting a philosophical way of understanding and investigating a philosophical problem.

O segundo livro de A República se abre com o pedido feito por Glauco a Sócrates, para que retome a discussão que ocupara boa parte da conversação com Trasímaco no primeiro livro, a respeito de sua definição de justiça como o interesse ou conveniência do mais forte e a conclusão de que, consequentemente, é melhor ser injusto do que justo. Convencido de que a questão não está decidida, de que não foi categoricamente afastada a tese do sofista em favor da posição contrária, como pretendeu Sócrates, Glauco repõe a posição de Trasímaco, para que Sócrates possa reexaminá-la (357 -362c). Esse pedido, logo a seguir, será reiterado e reforçado por Adimanto, irmão de Glauco, que desenvolve e esclarece as afirmações feitas por seu irmão (362d-367e).

Pretende-se aqui analisar essa retomada, para compreender seu sentido, intenção e principais características. Tal investigação não pode deixar de referir-se a alguns tópicos consagrados a esse respeito, que giram em torno do fato de que esse segundo livro parece abrir uma nova etapa no diálogo. É o próprio Sócrates, com efeito, que se refere a toda a conversação do primeiro livro como um "prólogo", um "prelúdio", um "proêmio" (prooímion, 357 ). Isso motivou a interessante questão sobre quais seriam as mudanças significativas do segundo livro em comparação com o primeiro, questão essa intimamente associada à da eventual existência de um anterior diálogo independente, 
denominado "Trasímaco", que Platão teria somente mais tarde transformado no primeiro livro de A República. Não interessa a este breve estudo propor qualquer solução para a segunda questão, que parece mesmo ser um tanto artificial, pois, ainda que Platão tenha escrito um semelhante diálogo, o fato é que mais tarde o terá reformulado e preparado para fazer as vezes de primeiro livro de A República, o que torna talvez impossível conjecturar com alguma segurança sobre qual teria sido seu conteúdo original. E se não podemos fazer conjecturas sobre seu possível conteúdo original, a pergunta sobre se de fato esse diálogo existiu perde muito de sua significação filosófica, tornando-se, afinal, apenas expressão de uma curiosidade histórica do intérprete $^{1}$.

O mesmo não se pode dizer da primeira questão, porque ela diz respeito à metodologia filosófica do platonismo, isto é, ela nos auxilia a compreender como Platão via a mais adequada maneira de filosofar. Isso nos coloca inevitavelmente diante do tema um tanto arriscado das relações entre um platonismo "maduro", no qual encontraríamos o pensamento do filósofo em toda a sua plenitude, e um certo "socratismo", tradicionalmente associado aos diálogos ditos de juventude, aporéticos em sua maioria, nos quais Platão estaria, por assim dizer, experimentando um estilo de reflexão filosófica ainda essencialmente tributário da interrogação socrática, que somente mais tarde e gradativamente o conduziria a uma forma própria de pensar. Desse ponto de vista, o primeiro livro de A República, tenha ou não sido escrito um dia como diálogo independente, serviria a Platão como meio de demarcar essa mudança, pois, ao repor no segundo livro a mesma questão "socraticamente" abordada no primeiro e dando-lhe novo tratamento, o filósofo estaria ao mesmo tempo indicando que o leitor tomará agora contato com uma nova maneira de lidar com a questão, uma maneira agora plenamente "platônica". Nesse sentido, uma mudança importante que o cotejo entre o primeiro livro e o restante do diálogo nos poderia mostrar diria respeito ao modo adequado de conceber as virtudes: não mais um saber à maneira de uma tékhne, como se observa em diálogos de juventude e de forte inclinação socrática, mas sim um saber

\footnotetext{
${ }^{1}$ Vale sobre isso mencionar o sintético veredicto de J. Annas: "mesmo que o livro I tenha sido escrito separadamente, isso não importa; ele compõe uma introdução inteiramente adequada à discussão principal" (An Introduction to Plato's Republic, Oxford, Clarendon Press, 1981, p. 17).
} 
cujo modelo agora é o "conhecimento teórico das matemáticas" ou algo que se formularia em termos semelhantes ${ }^{2}$.

Evidentemente, seria precipitado e talvez mesmo um grande equívoco da parte do intérprete admitir, como já se fez, que existe uma fronteira claramente visível, no conjunto dos diálogos, entre "socratismo" e "platonismo". Isso já significaria, em verdade, assumir o perigoso pressuposto de que o Sócrates dos diálogos não foi completamente um produto da escrita e do pensamento platônicos, como se Platão estivesse preocupado, em algum momento de sua trajetória intelectual, em fazer as vezes de historiador e biógrafo do mestre. Num sentido importante, embora seja produto de uma convivência inegavelmente profunda entre o discípulo e o mestre, tudo o que Sócrates diz e faz nos diálogos de Platão é na verdade Platão, é uma construção platônica cuja veracidade histórica importa menos do que a compreensão de seu significado no conjunto dos diálogos.

Contudo, isso não quer dizer que não se possam descobrir nesses diálogos alterações substantivas, relacionadas talvez a uma maior ou menor presença da influência socrática. Noutras palavras, não é preciso adentrar o pantanoso terreno do problema da demarcação de fronteiras entre socratismo e platonismo, para reconhecer a existência de mudanças filosóficas importantes, que podem ser expressas seja como um abandono, seja como um refinamento do estilo interrogativo tradicionalmente chamado de socrático que caracteriza diálogos de juventude, e que se dariam provavelmente junto com aquela reformulação do estatuto das virtudes. É nesses termos mais prudentes e moderados de uma investigação sobre a filosofia platônica que não se pergunta sobre um socratismo histórico, mas que reconhece a possibilidade de alterações significativas que podem ser expressas à luz da influência socrática, que podemos ler as páginas iniciais do segundo livro de A República como um momento expressivo dessa filosofia ${ }^{3}$.

\footnotetext{
${ }^{2}$ Essa transformação explica, segundo N. Pappas, a razão de ser do primeiro livro. $C f$. N. Pappas, Plato and the Republic, Routledge, London, 1995, p. 36.

${ }^{3}$ A defesa da existência de uma substantiva mudança filosófica na passagem do primeiro para o segundo livro parece predominar entre os estudiosos. Contudo, para uma análise que minimiza essa idéia e vê sobretudo continuidade entre o primeiro e os demais livros de A República, $c f$. C. Rowe: "The Literary and Philosophical Style of the Republic", The Blackwell Guide to Plato's Republic, G. Santas (ed.), Blackwell, 2006, p. 7-24, esp. p. 11. Cf. também C. H. Kahn, "Proleptic composition in the Republic, or why Book 1 was never a separate dialogue", Classical Quarterly 43 (i), 1993, p. 131-42.
} 
Uma primeira abordagem destas primeiras páginas do segundo livro de $A$ República deve ressaltar que, a bem dizer, Glauco e Adimanto retomam a tese de Trasímaco sob nova formulação. Isto é, não se trata simplesmente de repor os argumentos desse sofista, mas sim de apresentar a tese por ele defendida com uma roupagem distinta, recorrendo a um vocabulário que não é apenas uma reprodução da fala de Trasímaco. Nessa nova formulação, existem algumas características de evidente relação com a seqüência do diálogo, isto é, que expressam a tese de Trasímaco segundo uma terminologia que é bastante familiar à doutrina construída a seguir. Assim, um primeiro aspecto importante dessa retomada consiste nessa função que as intervenções de Glauco e Adimanto cumprem de, por assim dizer, traduzir a tese do sofista para uma nova linguagem, para um modo de falar mais condizente com tudo o que Sócrates dirá para defender a posição favorável à justiça. Portanto, de início estamos diante de alterações de vocabulário, indicativas e preparatórias para futuras reformulações de conteúdo. Vejamos quais são essas alterações.

Em primeiro lugar, Glauco faz uma distinção entre três tipos de bens - aquele que queremos possuir "amando-o por causa dele mesmo" (autò hautô̂ héneka aspazómenoi), como a alegria e prazeres inofensivos, aquele que "amamos por ele mesmo e pelo que dele decorre" (autó te hautô̂ khárin agapômen kaì tôn ap'autôิ gignoménon), como o pensar, o ver e o ter saúde, e os que "não por eles mesmos gostaríamos de tê-los" (autà heautôn héneka ouk àn dexaímetha ékhein), mas por "tudo que deles advém" (khárin...tôn állôn hósa gígnetai ap’autôn), como a ginástica e os cuidados médicos $(357 b-d)^{4}$. Após essa distinção, Glauco solicita a Sócrates que localize a justiça nessa divisão tripartite, observando desde já que os homens em geral consideram a justiça como um bem do terceiro tipo (357d-358a). E Adimanto a seguir observará que é a boa reputação que advém da justiça o que move os homens a fazer o elogio desta (362e-363a, 367b).

Observa-se também uma noção de "natureza", apenas sugerida no discurso do sofista no primeiro livro e ali pouco elaborada por Sócrates em sua argumentação, mas que agora é desenvolvida por Glauco, ganhando maior importância em sua formulação

\footnotetext{
${ }^{4}$ Será utilizada aqui a tradução feita por Anna Lia Amaral de Almeida Prado (São Paulo, Martins Fontes, 2006).
} 
da tese de Trasímaco: "Segundo dizem, por natureza, cometer injustiça é um bem e sofrê-la, um mal (pephykénai...tò mèn adikeîn agathón, tò dè adikeîsthai kakón)"; segue-se outra característica importante, a contraposição da natureza à lei: "e foi a partir de então que os homens começaram a estabelecer suas leis e convenções (nómous títhesthai kaì synthékas hautôn), e a chamar legal e justo (nómimon te kaì díkaion) o prescrito pela lei (tò hypò tô̂ nómou epítagma)" (358e-359a). Essa contraposição é mobilizada por Glauco em sua retomada da tese de Trasímaco, para expor a opinião corrente sobre a justiça.

Glauco põe a exigência de uma defesa e elogio da justiça "pelo que ela mesma é” (autò kath'hautó) (358d), vale dizer, Sócrates terá de declarar “o que é” (tí esti) cada uma, justiça e injustiça, "que capacidade tem uma e outra quando estão no íntimo da alma (tína ékhei dýnamin autò kath'hautò enòn en têi psykhêi)" (358b). Em termos semelhantes falará Adimanto: "Elogia, portanto, a justiça naquilo com que por si mesma (hò autè di’hautén) ela ajuda quem a tem" (367d). "Não nos mostres apenas que a justiça vale mais que a injustiça, mas também o que cada uma, por si própria, produz em quem as possui (tí poioûsa hekatéra tòn ékhonta autè di’hautén)" (367e). Para tanto, será necessário explicar "o que é a justiça e donde ela vem” (hô̂ón te hóthen gégone dikaiosýne) (358e), isto é, discorrer sobre sua "natureza" (phýsis) (359b), sua "origem" (génesis) e "essência" (ousía) (359a). É o que faz o próprio Glauco, quando reapresenta a tese de Trasímaco (359e e segs.).

Tais características terminológicas da intervenção de Glauco e Adimanto, que contêm evidentes diferenças em relação às afirmações de Trasímaco no primeiro livro, e o modo como eles as estabeleceram, parecem revelar o que já se chamou de "elementos prolépticos", “antecipações" em relação à seqüência da construção do diálogo, no que concerne aos conceitos e aos temas ${ }^{5}$.

\footnotetext{
${ }^{5}$ Cf. M. Vegetti, La Repubblica, vol. II, Libri II e III, Bibliopolis, 1998: "elementos prolépticos estão espalhados por toda parte nos dois livros e freqüentemente em posições conceitualmente relevantes" (p. 15). A idéia de prolepse foi desenvolvida sobretudo por C. H. Kahn. Para nossos propósitos, cf. seu artigo supracitado. A seguinte formulação parece uma eficiente justificativa para a busca de antecipações no diálogo: "é uma natural assunção, para uma obra escrita com tanto cuidado como a República, que as características mais notáveis das partes devam ser compreendidas nos termos de algum plano total para a obra como um todo" (p. 132). Guiado por essa forma de análise, Kahn defende a tese de que, na verdade, o possível "socratismo" dos diálogos de juventude não é deixado para trás: muito ao contrário, a doutrina dos livros seguintes de A República consistiria numa forma de voltar ao ataque, em favor da "posição moral socrática", cf. p. 135-6). Relevantes análises sobre antecipações presentes no livro II também se encontram em N. P. White, A Companion to Plato's Republic, Hackett, Indianapolis, 1979, p. 74-82.
} 
Exemplo paradigmático dessa nova e mais filosófica maneira de pôr o tema da justiça se percebe na argumentação de Glauco: contrastando natureza, por um lado, e convenção ou lei, por outro, ele prepara o caminho para uma nova desqualificação da posição de Trasímaco, que acorrerá mediante uma conciliação entre natureza e lei, conciliação que se obtém com a legitimação do governo do filósofo, que legisla à luz de uma natureza própria do real e munido de uma natureza filosófica exclusivamente sua, que o distingue. A idéia de que cada um deve fazer na cidade o que lhe compete por sua natureza, uma natureza que lhe é própria (370a-c, 374e), será a base para a concepção de justiça na cidade (423d, 433a, 453b-c, 454b, 456b), uma cidade - e uma alma - na qual "a impetuosidade ...por natureza é auxiliar da razão (tò thymoeidés, epíkouron òn tôi logistikôi phýsei)" (441a; cf. 443d). Agora, contudo, diferente do que se poderia depreender da tese de Trasímaco tal como reapresentada por Glauco, tratar-se-á de mostrar que a boa lei é aquela que é estabelecida "segundo a natureza (katà phýsin)" (456b-c). E que a alguns compete por natureza (phýsei) dedicar-se à filosofia e governar a cidade (474b-c; cf. também 485a-b), pois possuem uma "natureza filosófica (phýsis philósophos)" (485a, 486a) cuja correta educação torna-se a chave para o problema da cidade justa (cf. 489b, 514a, 519a; cf. 424a, 473d, 491e-492a). Noutras palavras, desafiando Sócrates a desqualificar uma concepção de justiça que se explica pela oposição entre o natural e o legal, Glauco introduz os termos da solução do problema da justiça, tal como ocorrerá na seqüência do diálogo: uma conciliação que legitima o governo do filósofo e a lei como expressão da natureza ${ }^{6}$.

Além disso, Glauco e Adimanto retomam a noção de alma, que Sócrates havia evocado no primeiro livro para estabelecer sua posição, dando-lhe agora, contudo, importância muito maior, permitindo a Sócrates tratar da justiça como algo ligado à alma do indivíduo e finalmente caracterizar o "verdadeiro filósofo (alethôs philósophos)" como aquele que, abandonando os prazeres corporais, se atém ao “prazer...só da própria alma" (perì tês psykhês...hedonèn autês kath’hautén)" (485d). Assim, quando é finalmente reconsiderada a tese de Trasímaco, no final do nono livro (590c e segs.), pode-se afirmar que a idéia de que é melhor cometer injustiça sem ser

\footnotetext{
${ }^{6}$ L. Strauss observa que a cidade que Sócrates, Glauco e Adimanto fundarão será, diferentemente de todas as outras, conforme à natureza. Nesse sentido, temos a desqualificação da idéia presente no discurso de Glauco de que a cidade é contrária à natureza. Cf. The City and Man, Univ. Chicago Press, 1978, p. 93. Para tanto, foi preciso que o jovem interlocutor de Sócrates retomasse esse tema e lhe desse uma importância que a discussão entre Sócrates e Trasímaco no primeiro livro não foi capaz de estabelecer. Cf. também White, op. cit., p. 80.
} 
percebido, como pretendeu Trasímaco no primeiro livro, e com ele Glauco e Adimanto no início do segundo, deve ser afastada, porque a punição da injustiça acalma a "ferocidade (tò theriôdes)", libertando-se o que há de doce, com "a alma toda, reintegrada em sua melhor natureza (eis tèn beltísten phýsin), adquirindo a temperança e a justiça juntamente com a sabedoria (sophrosýnen te kaì dikaiosýnen metá phronéseos)" (591b). A teoria da alma desenvolvida nos livros posteriores, ela também, provavelmente, uma inovação em relação a diálogos anteriores, tem no pedido de Glauco e Adimanto sua introdução, seu primeiro momento, pois os dois irmãos já tratam a justiça como uma característica da alma, retomando uma idéia apenas apresentada no final do primeiro livro por Sócrates (353d-e) ${ }^{7}$.

Por outro lado, também o vocabulário do "por si mesmo", da ousía e do tí esti, terminologia que, como se sabe, Platão consagra em alguns de seus diálogos, utilizado neste momento ainda introdutório, traz a discussão para um terreno propício à marcha da argumentação que conduzirá, no quarto livro, à divisão das partes da alma e à localização da justiça, bem como à apresentação da noção de Forma, com a qual Sócrates poderá construir uma doutrina sobre o real que fundamente a naturalidade e legitimidade da função do filósofo, de seu governo. As expressões autò kath 'hautó, por Glauco em 358b, génesis e ousía, também por Glauco em 359a, hò autèn di hautén por Adimanto em 367d-e, parecem já ter algum estatuto filosófico relevante e interessante, sem ainda possuir os significados filosóficos precisos e profundos que, neste diálogo ou em outros, Platão a eles confere ${ }^{8}$.

\footnotetext{
${ }^{7}$ A esse respeito, cf. Pappas, op. cit., p. 56.

${ }^{8}$ A expressão autò kath hautó, segundo Vegetti (op. cit., p. 27, n. 7), embora não tenha certamente o significado metafísico que Platão lhe confere em outros momentos de seus diálogos, "enfatiza o esforço de Glauco por uma abstração e conceitualização crescente da discussão sobre a justiça. Essa deliberada ênfase platônica sobre o papel de Glauco é sublinhada pelo fato de que a expressão não comparece noutro lugar do diálogo e em todo o corpus Glauco é o único a usá-la, com exceção dos discussion-leaders dos diálogos". Quanto a génesis kaì ousía, "a expressão não tem aqui certamente o valor ontológico que teria assumido sobretudo no Filebo. Comporta, antes, uma articulação da forma de resposta à pergunta socrática ti esti: o processo de formação do objeto condiciona e esclarece sua estrutura essencial. É exatamente desse modo que se articulará a investigação nos livros II-III (genesis) e IV (ousia da justiça)" (op. cit., p. 28, n. 9). E a propósito da expressão de Adimanto: "A linguagem da abstração conceitual, empregada nesta etapa do diálogo por Glauco e Adimanto (a partir de Trasímaco) bem mais do que por Sócrates, preludia aqui claramente aquilo que a seguir será utilizado na definição da teoria das idéias" (p. 47, n. 64). Sobre kath'hautó por Glauco, observa G. F. R. Ferrari que Glauco, certamente conhecedor da habitual interrogação de Sócrates, "está procurando aqui pela mais profunda explicação sobre a justiça que pode imaginar" (City and Soul in Plato's Republic, Univ. Chicago Press, 2005, p. 15). Para L. Strauss, Glauco "assume que pode responder à questão sobre o que é a justiça respondendo à questão sobre como a
} 
Note-se, finalmente, em que termos Glauco manifesta sua insatisfação com o final da conversação entre Sócrates e Trasímaco no primeiro livro: "Sócrates, tu queres que pareça (dokeîn) que nos persuadiste ou, de verdade (alethôs), queres persuadir-nos de que é absolutamente melhor ser justo que injusto"? (357a-b). Com esta terminologia certamente comum, mas que expressa uma distinção, como sabemos, fundamental para a noção de filosofia desenvolvida a partir do final do quinto livro, nosso personagem mais uma vez prepara o caminho para a introdução de significados precisos e filosóficos para termos correntes ${ }^{9}$.

De tudo isso resulta, diga-se de passagem, que seria então imprecisa a afirmação de que Glauco retoma a "argumentação" de Trasímaco, como se pode supor da frase: epananeósomai tòn Thrasymákhou lógon (358c). Trata-se mais precisamente de, literalmente, "renovar" o que Trasímaco disse, o que torna mais adequado dizer que não é a "argumentação" de Trasímaco que se retoma, mas sim sua tese, sua afirmação (lógos), para conferir-lhe nova versão e roupagem. É o que faz Glauco ao introduzir suas novas formulações, que, ao mesmo tempo em que retomam o conteúdo da tese do sofista, já o fazem em conformidade a uma terminologia filosófica mais adequada.

Percebe-se, em suma, que algumas análises e teses que aparecerão mais tarde na construção da cidade e no estabelecimento de sua justiça prenunciam-se e preparam-se neste momento introdutório, tornando-se assim tal intervenção de Glauco e Adimanto o meio necessário para que ocorra a bom termo o desdobramento dessas teses centrais. Dito de outro modo, Glauco e Adimanto trazem o problema para seus devidos termos e conceitos, revelando-se, nessa medida, como iniciados na tábua conceitual que Sócrates irá mobilizar ao longo do diálogo ${ }^{10}$.

justiça vem a ser: o 'o que' ou natureza da justiça é idêntico a seu vir a ser” (op. cit., p. 86). A esse respeito, destaque-se também o termo eîdos em 357c, empregado por Glauco a respeito do terceiro tipo de bem. Evidentemente, o termo, nessa passagem, tem ainda, como diz Vegetti, um sentido "não técnico e ontológico", mantendo "o sentido semiclassificatório de 'aspecto' ou 'tipo'...é só a partir do livro V que eidos/idea poderão adquirir um sentido teórico mais preciso" (op. cit., p. 26, n. 3). Vale registrar, contudo, a necessidade de iniciar o emprego desse termo e de todo esse vocabulário, para que possa ser refinado, sendo essa a função de Glauco e Adimanto aqui.

${ }^{9}$ Para a importância dessa distinção nos discursos de Glauco e Adimanto, cf. White, op. cit., p. 81.

${ }^{10}$ Kahn, art. cit., p. 139: "A afirmação na sentença final do livro 1, de que devemos saber o que é a justiça antes que possamos saber se quem a possui será feliz, define o programa para os livros 2-4. Devemos nos envolver numa nova (e desta vez bem sucedida) tentativa de definir a justiça, a fim de responder adequadamente ao desafio de Trasímaco, tal como reformulado por Glauco e Adimanto". Cf. também I. H. Jang, "Socrates Refutation of Thrasymachus", History of 
A diferença de terminologia não basta, contudo, para explicar o papel desempenhado pelos dois irmãos no início do segundo livro. Com efeito, essa diferença é acompanhada de outra de mesma importância, que talvez se deva caracterizar como uma mudança de atitude, e que está intimamente associada àquela mudança de vocabulário. E não é, como veremos, por simples coincidência que essa associação ocorre.

O que disse Glauco a Sócrates, quando declarou que iria reafirmar a posição de Trasímaco? Antes de expor o que os homens julgam ser a justiça e sua origem, bem como os motivos de a seguirem contra suas vontades, Glauco acrescenta: "A mim parece que não é assim... Não tenho, porém, o que dizer (aporô), porque nos meus ouvidos estão zumbindo as palavras de Trasímaco e de milhares de outros (diatethryleménos tà ôta, akoúon Thrasimákhou kaì myríon állon); mas um discurso em defesa da justiça, que diga que ela é melhor que a injustiça (tòn dè hupèr tês dikaiosýnes lógon, hos ámeinon adikías), isso ainda não ouvi de ninguém, da maneira que eu quero (hos boúlomai); quero ouvir (boúlomai akoûsai) um elogio pelo que ela mesma é (autò kath 'hautó) e penso (oîmai) que de ti eu ouviria isso" (358c-d).

Esta passagem é bastante rica e sugestiva. Inicialmente, observe-se que Glauco se declara em aporía, sem saber o que dizer. Mas isso não o transforma num exemplar daquela galeria de interlocutores que Sócrates se comprazia em confundir nos diálogos de refutação. Na verdade, Glauco concorda com Sócrates, assim como seu irmão Adimanto, a respeito da superioridade da justiça. O problema é que a tese de Trasímaco é aceita por muitos na cidade e isso acaba produzindo uma situação de embaraço, pois sua crença se vê, repentinamente, desprovida de boas razões que a fundamentem. Glauco, portanto, aparece como alguém que precisa de uma boa razão para crer no que crê, o que só é possível pela adequada refutação da tese contrária. Isto é, importa-lhe sobretudo como se deve defender a tese em favor da justiça e isso ele não conhece. $\mathrm{O}$ vocabulário filosófico - autò kath hautó - se associa a uma exigência também filosófica: “quero ouvir um elogio pelo que ela mesma é...". Ora, isto já é indicativo do

Political Thought, vol. XVIII, n. 2, 1997, p. 206. Para uma outra visão do livro I que nele encontra positividade, cf. Strauss, op. cit., p. 83-4: se não se descobre aí o que é a justiça, constata-se qual é o problema - a tensão a suprimir entre bem individual e bem comum. Essa tensão, a nosso ver, se torna claramente perceptível nas intervenções dos dois irmãos. 
perfil intelectual e filosófico dos irmãos, que os distingue dos interlocutores anteriores do primeiro livro ${ }^{11}$.

Com esse novo perfil, estamos em condições de compreender melhor o que doravante estará em jogo no diálogo. Quando Glauco diz que está com os ouvidos cheios da tese de Trasímaco, defendida por milhares, pode-se talvez imaginá-lo, e a seu irmão Adimanto, ouvindo todo aquele barulho produzido nas assembléias, nos tribunais, nos teatros, nos acampamentos ou em qualquer outra reunião pública (492b), presenciando a ação daqueles indivíduos chamados de sofistas, que ensinam as doutrinas da maioria, aquilo mesmo que o vulgo pensa, aprendendo a discernir o que agrada ou não à massa, como se tratasse com uma grande fera, e a isso chamando de "sabedoria" (sophía) (493a-c). Os dois irmãos são, portanto, vítimas potenciais daquele “ensino" que, para Platão, explica até o preconceito contra a filosofia na cidade e o fracasso da educação dos jovens. No entanto, o início do segundo livro mostra que eles têm, digamos assim, uma visão própria e crítica dessa cultura sofística. Glauco, na passagem supracitada, revela que consegue se preservar dessa cultura, mostrando independência, embora não consiga desqualificá-la. É essa independência, essa autêntica autonomia, o que move as intervenções dos irmãos e lhes confere papel especial.

Contudo, há mais. Não é somente em relação ao falso saber do sofista que se afirma a independência de Glauco, e isso já se pode perceber no início de sua intervenção: "ao que me parece, mais cedo do que devia, Trasímaco deixou-se encantar (kelethênai) por ti como uma serpente...Para mim, porém, de um e outro lado, a argumentação não decorreu de acordo com a razão (emoì dè oúpo katà noûn he apódeixis gégonen perì hekatérou)" (358b). É curioso, e talvez sintomático, que Glauco tenha utilizado, para falar dos efeitos da interrogação socrática sobre Trasímaco, o mesmo vocabulário que o próprio Sócrates, no último livro, empregará para se referir aos efeitos que as palavras dos poetas podem produzir: um "tal...encantamento...por

${ }^{11}$ Sobre a atitude e perfil de Glauco, parecem-nos adequadas as seguintes observações de D. H. Rice: "o ponto sobre o retrato platônico de Glauco, contudo, é que, ainda que ele diga que rejeita a opinião dominante sobre a justiça, não está em melhor posição do que Trasímaco, a não ser que saiba por que a rejeita. Glauco admite que não sabe por que a opinião que rejeita está errada. Ele quer acreditar que a justiça é algo mais nobre e digno, que é um bem em si mesmo e que quem pratica a justiça como um fim em si mesmo seria a pessoa verdadeiramente mais feliz, mas ele não tem razões para sustentar essa opinião. Assim, ele pede a Sócrates que demonstre a verdade daquilo em que ele quer acreditar" ( $A$ Guide to Plato's Republic, Oxford Univ. Press, 1998, p. 36-7). Cabe apenas ressalvar que em nenhum momento Glauco parece descrer da superioridade da justiça. 
natureza (phýsei...megále kélesis)", parecendo falar bem (eû dokeîn légesthai) àqueles que se deixam levar por palavras (601a-b). Glauco, então, consegue ver o procedimento socrático, seu estilo de interrogação, daquela mesma forma autônoma e independente, e talvez se possa mesmo dizer: de um ponto de vista crítico. Quando retoma a tese de Trasímaco, o faz, portanto, não somente para que seja refutada, mas também porque não se satisfez com o método empregado por Sócrates. Observe-se que Glauco se declara insatisfeito com ambas as argumentações (perì hekatérou), isto é, com a maneira como havia sido posto e desenvolvido o tema ${ }^{12}$.

Passa então a fazer sentido a idéia de que estamos diante de uma espécie de demarcação dos limites desse método, tal como exercitado no primeiro livro, e diante também da constatação de sua inadequação e insuficiência. Assim, quando Glauco afirma estar em embaraço (aporô), porque não crê na tese de Trasímaco, mas ela o assalta todo o tempo, ele denuncia também um certo fracasso da investigação, fracasso que o próprio Sócrates expressou no final do primeiro livro e que o jovem retoma: não se pode falar sobre as vantagens ou desvantagens da justiça sem antes saber o que ela é (354b-c). A aporia, agora, além de ponto de chegada de uma investigação, é ponto de partida para uma outra, substancialmente nova, cujo procedimento Sócrates terá de propor, em virtude das exigências de seus novos interlocutores.

Mas isso significa também que é preciso fazer certas distinções entre as intervenções de Glauco e as de seu irmão, Adimanto. Este também desempenha papel importante e pudemos detectar as características relevantes de seu discurso. Contudo, observando sua intervenção no início do segundo livro, quando endossa a retomada que Glauco faz da tese de Trasímaco, percebe-se sua forte ligação com a autoridade dos poetas: ele inicia sua intervenção citando "o bom Hesíodo e Homero" (363a-c). Além disso, alguns de seus argumentos apresentam-se como uma expressão do discurso "das pessoas comuns e dos poetas (idíai te legómenon kaì hypò poietôn)" sobre a justiça e a

\footnotetext{
${ }^{12}$ Sobre o verbo keléo usado por Glauco, Vegetti observa seu significado tradicional de "encantar", relacionado a Orfeu, e comenta sua ocorrência em algumas outras passagens de Platão (op. cit., p. 26, n. 5). Parece-nos, contudo, que é preciso ir mais longe e destacar que Glauco, nesse momento, considera Sócrates da mesma forma que, mais tarde, Sócrates considerará os poetas, o que dá ao emprego desse verbo uma conotação crítica bem mais forte do que poderia parecer à primeira vista. $\mathrm{O}$ que torna relevante a observação desse emprego da terminologia e a conclusão de que ela é expressiva de algo que Platão nos quer comunicar - o olhar crítico de Glauco a respeito de Sócrates - é o fato de Platão ter sido extremamente cuidadoso e meticuloso na confecção de seus diálogos. A esse respeito, lembremo-nos da conhecida afirmação de Dionísio de Halicarnasso (de Compositione Verborum) de que Platão nunca deixou de trabalhar neles.
} 
injustiça (363e). Pode-se talvez dizer que, visando a reforçar a posição de seu irmão, o que o aproxima dele, Adimanto o faz, no entanto, optando por se travestir de porta-voz de um certo "senso comum" que vê na fala dos poetas um saber significativo. Não será provavelmente por outro motivo que a análise da poesia a partir do segundo livro se dê com Adimanto como interlocutor, porque é ele quem se preocupa com o conteúdo da poesia e sua dimensão educativa (376d e segs.). Sua posição, intimamente associada à atitude intelectual de Glauco, é, contudo, mais voltada para os saberes estabelecidos, ainda que não os endosse sistematicamente. Adimanto nalguma medida os respeita e permanece atento ao que pensa a maioria. Por isso, também lhe caberá, no sexto livro, observar a Sócrates o que a cidade pensa dos filósofos, lembrando a inutilidade ou perversidade que lhes é atribuída por essa mesma cidade (487b-d). Adimanto, numa palavra, explora os poetas, sua autoridade, para elaborar sua argumentação.

Glauco é mais independente disso, está mais afastado da dóxa. É verdade que em seu discurso ele também se refere a um poeta, Ésquilo, para quem o homem simples e generoso não quer parecer, mas ser justo (361b). Mas há diferenças importantes. Glauco, na verdade, para reafirmar a tese de Trasímaco, inverte o sentido do dito do poeta: "será muito mais correto aplicar ao injusto o que Esquilo diz" (362a). A poesia é aqui usada por ele como contraponto, como simples instrumento, não como autoridade. Por isso, embora não seja correto concluir que Adimanto é mero defensor da poesia tradicional e de sua influência popular, certamente pode-se estabelecer uma diferença importante no perfil intelectual dos dois irmãos, com base na distinção do valor concedido por cada um a esse fato cultural de importância incontestável ${ }^{13}$.

\footnotetext{
${ }^{13}$ Parece-nos excessivamente negativo o tom da descrição dos dois irmãos feita por Pappas, para quem eles se distinguem de interlocutores de diálogos anteriores por sua docilidade e passividade, ao mesmo tempo que têm curiosidade e disciplina (op. cit., p, 50-1). Na mesma direção vai A. Bloom, ao ver a possibilidade de que os dois irmãos possam tornar-se discípulos de Trasímaco (cf. The Republic of Plato, Basic Books, 1991, p. 339-40). Também soa excessiva a distinção feita por esse intérprete entre a "ousadia" de Glauco e a "moderação" de Adimanto, embora, por outro lado, seja interessante distingui-los nestes termos: "Glauco volta-se para a natureza, Adimanto para a opinião; enquanto Glauco presta atenção no que viu, Adimanto presta atenção no que ouve. Ele é particularmente afeito à poesia” (p. 342). Encontra-se em S. Bernadete uma formulação a nosso ver pertinente: o papel de Adimanto é "preparar o caminho para a renovação da antiga querela entre poesia e filosofia", enquanto Glauco "prepara o caminho para um confronto entre a filosofia e a cidade" (Socrates`Second Sailing - on Plato`s Republic, Univ. Chicago Press, 1989, p. 42). L. Strauss também distingue os dois, opondo a coragem de um à moderação do outro, de uma forma, a nosso ver, um tanto simplificada (cf. op. cit., p. 90-1).
} 
Ao retomar a palavra após as intervenções dos dois irmãos, Sócrates louva uma capacidade que Glauco e Adimanto possuem: defender uma tese que não é de fato objeto de suas crenças (358d, 361d-e, 367a-b 368a-b). E Sócrates está convencido de que eles realmente defendem a posição oposta àquela que provisoriamente vão sustentar em nome de Trasímaco, movidos exatamente pela esperança de encontrar a boa forma de afastá-la.

Essa característica da intervenção dos dois irmãos é emblemática daquilo que será talvez a grande marca distintiva dessa reformulação proposta a partir do segundo livro. Para compreendê-la, observemos em que termos se dá o comentário de Sócrates a respeito dessa característica, ao tomar a palavra. Sócrates neles julga haver algo divino (thê̂on) e acrescenta: “O que me parece é que, de verdade, não estais convencidos. Dáme testemunho disso todo o vosso modo de ser (tô̂ állou toû hymetérou trópou), pois só pelo tom dos discursos (katá ge autoùs toùs lógous) desconfiaria de vós" (368a). É necessário concluir, desta fala de Sócrates, que a distinção entre os irmãos e Trasímaco certamente se explica pela diferença de trópos entre eles. Isto é, podemos avaliar se alguém realmente endossa o conteúdo do lógos que profere, observando seu trópos. E a tese de Trasímaco, não há dúvida, cai como uma luva em sua própria vida, enquanto os dois jovens revelam em sua conduta, em seu "modo de ser", que não defendem de fato o que aqui defendem provisoriamente. Eis por que Sócrates está convencido disso ${ }^{14}$.

Isso nos conduz a uma tese que parece ter adquirido importância crescente aos olhos de Platão, porque sua presença vai-se tornando cada vez mais visível em seus diálogos, ganhando talvez em A República seu tratamento mais completo. Podemos formulá-la agora nos seguintes termos: a marcha da investigação filosófica não se dá a contento, se o diálogo não for conduzido por participantes que exibam uma maneira filosófica de ser. Glauco e Adimanto seriam, pois, exemplos paradigmáticos desse trópos sem o qual o diálogo não consegue alçar vôos mais altos.

\footnotetext{
${ }^{14}$ Sobre o emprego de trópos em contraste com lógos, cf. Fédon, 58e, a propósito do próprio Sócrates, segundo a impressão de Fédon: "esse homem me parecia feliz, Equécrates, a avaliar pelas suas palavras e atitudes (kaì toû trópou kaì tôn lógon), tal a segurança e nobreza com que enfrentou o fim". E também 59b, a respeito de Apolodoro, cuja "maneira de ser" (trópos) apaixonada é bem conhecida. Trad. Maria Teresa Schiappa de Azevedo, Unb/Imprensa Oficial, 2000 .
} 
Não se trata, contudo, de propor que o diálogo exige a "sinceridade" dos participantes, isto é, que acreditem realmente no que dizem, mas sim que eles sejam possuidores não somente das capacidades intelectuais adequadas, como aquelas que permitiram aos dois irmãos formular com muito mais valor filosófico a tese de Trasímaco, mas também de um, digamos assim, temperamento e visão de mundo adequados ao filosofar. Defender uma tese como estratégia para encontrar a boa via de sua refutação dá mostras de um trópos filosófico e de uma visão correta do que vem a ser a função do diálogo, entendido como caminho para a descoberta da verdade.

Por isso, se é possível que a famosa expressão "ó filhos de ilustre homem" (368a) usada por Sócrates diga respeito a Trasímaco, "pai” da tese reposta pelos dois irmãos, e não a Aríston, seria um erro concluir que eles compartilham uma visão de mundo, um estilo de pensamento ou conjunto de valores que os tornariam realmente seguidores do referido sofista ${ }^{15}$.

Se assim for, poderemos concluir que o primeiro livro e o início do segundo livro de A República apresentam também uma espécie de ajuste de contas com uma situação que, a bem dizer, já se apresentava com clareza em diálogos como Protágoras e Górgias, dos quais talvez seja correto afirmar que, entre outros objetivos, pretenderam exibir dramaticamente os impasses resultantes do confronto entre uma dialética ainda de forte inspiração socrática e certos expedientes erísticos, reveladores de uma concepção do uso do discurso que Platão planejou, inegavelmente a partir da influência socrática, desqualificar. E essa desqualificação será, ao mesmo tempo, a superação ou sofisticação de uma dialética eminentemente refutativa, mobilizada pela personagem Sócrates nos primeiros diálogos, em benefício, agora, de uma nova concepção do diálogo como via para a verdade. A substituição de Trasímaco por Glauco e Adimanto na formulação da tese de Trasímaco consistirá, portanto, na viabilização do tratamento filosófico de uma tese que, até então, tinha seu valor intrínseco obscurecido pelo trópos deste sofista.

Desse ponto de vista, o início do segundo livro, operando a introdução das personagens de Glauco e Adimanto, teria uma função de extrema importância: agora, a partir do procedimento "socrático" devidamente superado ou depurado, obtêm-se

${ }^{15}$ A esse respeito, cf. M. Burnyeat: "Fathers and Sons in Plato's Republic and Philebus", Classical Quarterly 54.1, 2004, p. 80-87: “O que Sócrates está celebrando principalmente em República 2 não é a coragem física que os irmãos de Platão mostraram em Megara em seus dias de juventude, quando Glauco tinha um amante, mas sua presente coragem intelectual no campo de batalha do debate dialético" (p. 82). Essa "coragem intelectual" define um modo de ser dos irmãos. Parecem-nos, portanto, excessivos os comentários de Vegetti a esse respeito, ao falar de uma "marca trasimaquiana" no estilo de pensamento dos irmãos - op. cit., p. 152-3. 
ganhos filosóficos inéditos. Tais ganhos só serão possíveis mediante uma substancial reformulação do sentido mesmo do diálogo como meio de investigação, o que vale dizer, mediante uma alteração significativa do perfil dos interlocutores de Sócrates.

Torna-se então de extrema relevância recordar que o primeiro livro de $A$ República termina à maneira do Protágoras, com a constatação de que se examinou uma questão sem antes examinar-se uma outra, que lhe é anterior: comparando-se a um glutão, Sócrates reconhece que se pôs precipitadamente a examinar, antes de saber o que é a justiça, se ela é virtude ou vício, saber ou ignorância, e se é mais vantajosa do que a injustiça (354a-c) - assim como, no Protágoras, constatava que não se pode saber se a virtude pode ser ensinada sem antes saber o que é a virtude $(361 \mathrm{c}-\mathrm{d})^{16}$. Paralelamente a essa investigação, este diálogo exibe, na conversação entre Protágoras e Sócrates, um impasse: defensor e divulgador do "discurso longo" (makròs lógos), Protágoras não consegue atender à solicitação de Sócrates para que faça um "discurso breve" (mikròs lógos), que, segundo este, é a única forma de tentar resolver a questão que os move, a do ensino da virtude (334c-335c). Nesse momento crítico do diálogo talvez um momento crítico também do pensamento de um jovem filósofo que almeja aliar a influência decisiva de seu mestre a um conjunto de questões e temas próprios -, Pródico, que pode ter exercido alguma influência frutífera sobre Sócrates, dá vazão a sua inclinação um tanto excessiva à distinção de significado das palavras e, com o intuito de evitar a dissolução da reunião, afirma: “é, de fato, necessário que, aqueles que assistem a discussões destas ouçam ambos os interlocutores, de modo imparcial, mas não passivo - é que são coisas diferentes. É preciso ouvir os dois do mesmo modo, mas não atribuir a cada um o mesmo valor, antes mais ao mais sábio e menos ao mais ignorante. Pela minha parte, Protágoras e Sócrates, suponho que concordarão em discutir (amphisbeteîn) sobre os argumentos mas sem contender (erízein) - é que os amigos discutem com os amigos, com cordialidade (amphisbetoûsi mèn gàr kaì dì eúnoian hoi phíloi tô̂s phílois), enquanto que aqueles que contendem são os que estão em desacordo e se odeiam uns aos outros (erízousin dè hoi diáphoroí te kaì ekhthroì allélois) - assim, a nossa conversa (synousía) será muito melhor" (337a-b) ${ }^{17}$. Essa intervenção de Pródico faz o contraponto à idéia de philonikía, de desejo de vitória na conversação, que pouco antes fora apresentada por outros ouvintes da conversa (cf.

\footnotetext{
${ }^{16}$ cf. Kahn, art. cit., p. 134.

${ }^{17}$ Tradução de Ana da Piedade Elias Pinheiro, Lisboa, Relógio D`Água Editores, 1999.
} 
336b-e) e que estava também na base da resistência de Protágoras, que há pouco dissera que não conseguiria obter, nos combates verbais, fama e aparência de superioridade se fizesse como Sócrates pediu (335a). Ora, com isso, para Sócrates é o próprio trópos tôn dialógon que se vê ameaçado - para retomar o contexto do segundo livro de $A$ República, é a própria maneira de ser do dialogar, sua especificidade enquanto exercício da reciprocidade dos discursos, que se esvai (336a-b).

Por mais caricatural que seja a intenção de Platão neste momento do Protágoras, ao apresentar o sofista Pródico, percebe-se que sua intervenção contém idéias que nos auxiliam a compreender a mudança ocorrida no segundo livro de A República. Pois se havia algo impossível de encontrar no diálogo entre Sócrates e Trasímaco no primeiro livro, eram certamente philía e éunoia, amizade e cordialidade ou benevolência. Ora, assim como Pródico propunha um emprego e exercício do lógos que não visasse à philonikía, ao apego à vitória, apego esse que o Sócrates do Protágoras não tinha, é preciso agora, afastados Trasímaco e seu trópos, executar essa proposta, que naquele diálogo fora apenas anunciada e esboçada ${ }^{18}$.

Também no Górgias o tema do modo de condução do dialogar se desenvolve por uma tensão gerada pela tendência ao discurso longo (makrología) do impetuoso Polo, que Sócrates lhe solicita evitar: "se te puseres a falar longamente, sem querer responder às minhas perguntas, não serei eu o infeliz se não me for permitido partir sem te escutar? Mas se te interessa a discussão aqui travada e queres retificar alguma coisa, volta, como te disse, ao ponto que quiseres, interrogando e respondendo, como eu e Górgias fizemos, refutando e deixando-se refutar" (461e-462a) ${ }^{19}$. A dificuldade de obtenção de um acordo mínimo entre as partes é acentuada pela dificuldade do próprio Sócrates para tratar o tema em questão, a retórica, sem ele mesmo logo incorrer naquilo que pedia a seu interlocutor que evitasse: "Foi talvez um procedimento estranho o meu, de te proibir os longos discursos para depois me espraiar tão longamente, mas tenho para isto uma desculpa: enquanto te falei concisamente, não me entendeste bem nem foste capaz de aproveitar nada das respostas que te dei; estavas sempre a pedir explicações” (465e). São grandes os obstáculos para Sócrates: seu interlocutor não

\footnotetext{
${ }^{18}$ Parece-nos mesmo correto dizer que o Protágoras, além de pôr o tema da ensinabilidade da virtude, tem também como objetivo principal desenvolver esse tema do próprio sentido do dialogar. A esse respeito, permitimo-nos remeter o leitor a nosso "O cênico no Protágoras", Clássica, São Paulo, v. 13/14, n. 13/14, 2000/2001, p. 219-31.

${ }^{19}$ Tradução de Manuel de Oliveira Pulquério, Lisboa, Edições 70, 2000.
} 
parece capaz de se adaptar às necessidades do procedimento dialogado, o que nos põe numa atmosfera bastante próxima à do Protágoras. Essa atmosfera, contudo, parece tornar-se muito mais pesada no Górgias, porque neste diálogo a possibilidade de rompimento da conversação se dá em termos bem mais fortes com Cálicles, cuja irritação com o procedimento socrático vai crescendo gradativamente (cf. 489b-c, 494d495b, 497c, 499b-c), até o ponto em que Cálicles propõe que Sócrates interrogue outro (505c-e). Convencido por Górgias a permanecer, Cálicles, na verdade, apenas assente ao que Sócrates diz, criando uma situação peculiar: a maior parte do tempo, na seqüência do diálogo, Sócrates fará intervenções mais extensas do que gostaria, rendendo-se, até certo ponto, ao expediente da makrología que tanto se esforçara por evitar. Eis o sinal categórico do fracasso do procedimento dialógico.

Ora, observe-se quão difícil é também, no primeiro livro de A República, o diálogo entre Sócrates e Trasímaco. O clima é de animosidade e a maneira de ser de Trasímaco, seu trópos animalesco, dá o tom de uma conversação que não consegue avançar um passo sem que o vocabulário bélico venha à tona. Para Trasímaco, trata-se, em verdade, de um combate, não de um diálogo.

Assim, Trasímaco, que desde o início procurava o elogio dos presentes (338a), acusa Sócrates de ser um "homem caviloso" no que diz (sykophántes...en tô̂s lógois) (340d), um "nojento" (bdelurós) que desvirtua todo o seu discurso (338d). Trasímaco vê em Sócrates intenções de "impor-se pela força (biásasthai)" (341b) e se mantém em posição de combate, relutante (342d: mákhesthai). Sócrates pede a Trasímaco que responda de acordo com sua opinião, para o bom termo da discussão (346a). E insiste: "não devemos desistir de prosseguir nossa discussão, até eu sentir que estás dizendo o que pensas" (349a). A muito custo Trasímaco concorda com Sócrates e suas teses, mas com grande dificuldade (350d), adotando então uma atitude condescendente, com certo sarcasmo (351c-d, 352b, 354a).

Antes disso, tendo despejado seu longo discurso e preparado já para sair, Trasímaco é constrangido pelos presentes a explicar o que disse. Já irritado, o sofista retruca a Sócrates: "se não estás persuadido com o que há pouco dizia, o que posso fazer-te ainda? Pegar minha argumentação e enfiá-la dentro de tua alma?” (345b). A violência faz parte de suas intervenções e ele é pintado como um animal feroz (theríon) por Sócrates, logo em sua primeira intervenção $(336 b)^{20}$.

\footnotetext{
${ }^{20}$ Evidentemente, uma tal comparação só seria completa com uma análise das semelhanças e diferenças entre as personagens de Trasímaco e Cálicles, bem como de suas respectivas teses.
} 
Ora, o início do segundo livro, fazendo Trasímaco sair da cena ao mesmo tempo em que nela manteve sua tese, teve então como um de seus efeitos, talvez o principal, desanuviar essa atmosfera pesada. Isso quer dizer que agora os interlocutores poderão examinar tal tese em si mesma, isto é, considerá-la e analisá-la de modo a dela extrair seu rendimento filosófico próprio. Para isso, é necessário um novo modo de abordá-la, desprovido da selvagem philonikía de seu defensor originário.

Glauco está plenamente consciente desse seu papel. Embora, nas palavras de Sócrates, cumpra sua tarefa de renovar a tese de Trasímaco "com vigor" (erroménos) (361d), ele sabe que não é esta a melhor maneira de tratar o tema, pois alerta: "se minha linguagem for rude demais (agroiotéros), lembra-te, Sócrates, que não sou eu quem fala (mè emè...légein), mas os que, em vez da justiça, elogiam a injustiça” (361e). A tese de Trasímaco não é completamente separável da visão de mundo que a gera, ela terá sempre de ser apresentada com alguma "rudeza". Mas Glauco a trouxe, na medida do possível, para o patamar filosófico em que deve ser investigada.

A sequiência do diálogo, já em momentos mais desenvolvidos da investigação, fornece algumas indicações sobre as condições necessárias para o correto procedimento dialogado, as quais Trasímaco não preenche, pois a grosseria (agría) não poderia participar da filosofia (486b), nem a falta de medida (ametría), estranha à verdade, como uma natureza "sem afinidade com as musas (ámousos) e carente de graça (áskhemos) (486d). Por outro lado, o diálogo corretamente conduzido torna possível até mesmo a afirmação das mais polêmicas teses, já que, diz Glauco a Sócrates, "aos teus ouvintes (hoi akousómenoi) não falta nem discernimento, nem confiança, nem boa disposição" (oúte...agnómones oúte ápistoi oúte dýsnoi)" (450d). Disso, aliás, dá testemunho o próprio Glauco, imediatamente após ouvir a mais escandalosa das teses de Sócrates, aquela que afirma que, para a salvação das cidades, o filósofo deve governar, ou o governante, filosofar: "não te trairei e defenderei com as armas que posso - e é com boa vontade (eunoíai) e exortações (tôi parakeleúesthai) que posso (dýnamai) $(474 a)^{21}$.

Sem nos aprofundarmos nesse tema, podemos remeter o leitor a Annas, op. cit., p. 49: o ideal do segundo é o mesmo do primeiro, que o expressa, contudo, "em termos de poder político". Sobre as semelhanças entre o estilo argumentativo nos dois casos, cf. p. 56-7.

${ }^{21}$ Os poucos momentos de retorno de Trasímaco na seqüência do diálogo (cf. 450a-b, 498c-d) serão sempre mais pacíficos, mas ao custo de um silêncio quase absoluto. Se Trasímaco não mais interfere com suas atitudes ameaçadoras, isso não se deveu a nenhuma mudança de sua posição: ele não mais pode ser salvo pela filosofia. O máximo que se pode fazer é diminuir sua atuação. Glauco, por outro lado, é capaz de observar e constatar o "encantamento" de Trasímaco 
Essa nova forma de conceber o diálogo como meio e elemento em que se dá a busca da verdade permitirá talvez recuperar aquele procedimento que, no Protágoras e no Górgias, fora ponto importante de controvérsia e motivo forte de discórdia: o discurso longo. É interessante registrar o comentário de Sócrates, no início do sexto livro, após ter estabelecido com Glauco a distinção entre o filósofo (philósophos) e o amigo da opinião (philódoxos): "embora a discussão tenha durado muito (dià makrô̂ tinos...lógou), foi a custo que ficou evidente quem são uns e quem são os outros"; ao que responde Glauco: "Se a discussão fosse breve (dià brakhéos), talvez não fosse mais fácil" (484a). A necessidade de um discurso longo tem de ser notada, talvez por ser atípica da nova forma do filosofar pelo diálogo, embora, a bem dizer, nada semelhante aos discursos longos tradicionais tenha ocorrido. O que importa é que tal "direito à makrología" 22 se legitima, porque agora esse expediente é motivado por uma atitude intelectual que não o torna um empecilho à investigação.

Isso justifica também que Glauco e Adimanto tenham utilizado sem reprovação, em suas intervenções, esse expediente tão criticado por Sócrates em seus interlocutores. Talvez não houvesse realmente outra alternativa: a posição de Trasímaco só poderia ser expressa num discurso longo, pela sua própria constituição e pela postura de seu defensor. Como então traduzi-la filosoficamente? É preciso render-se, na medida do necessário, às características de seu modo de pensar, sem, no entanto, reter sua atitude passional. Assim compreende-se também o estratagema de Glauco, ao apresentar a posição de Trasímaco ao mesmo tempo mediante uma tese sobre a natureza humana e um relato mítico, o episódio do anel de Giges (359c-360d). Se no Protágoras o sofista de mesmo nome se dispunha a defender sua posição indiferentemente por um mýthos e por um lógos que se completariam (cf. 320c), aqui o expediente da narrativa fabular serve a um novo propósito, porque está subordinado a uma nova intenção. O mesmo valeria então para o recurso à poesia, presente sobretudo com Adimanto, mas também na rápida alusão de Glauco a Ésquilo ${ }^{23}$.

por Sócrates e evitá-lo, justamente porque não é um refutador à maneira de Trasímaco, não está em busca da vitória, não é movido por philonikía.

${ }^{22}$ Cf. Vegetti, op. cit., p. 151.

${ }^{23}$ Sobre a significação da presença de Glauco e Adimanto como interlocutores de Sócrates, no lugar de Trasímaco, afirma J. Lear que, enquanto este "possui já uma visão de mundo e tenderá a reconhecer argumentos bons e ruins nos termos dessa visão", Glauco e Adimanto, por sua vez, "são jovens e excepcionais (II. 367e-368b). São capazes de fazer um impressionante desafio à justiça e ainda não estão convencidos por seus próprios argumentos" (J. Lear, "Allegory and Myth in Plato's Republic", Blackwell Guide to Plato's Republic, G. Santas (ed.), Blackwell, 
Deste novo ponto de vista, pelo qual o diálogo é visado como um método de construção filosófica, aquilo que se constituía em problema nos embates entre Sócrates e seus interlocutores ganha novo significado. Com Polo, Cálicles e Trasímaco, Sócrates insistia na necessidade de dizer o que realmente se pensa e acredita, isto é, fazia a exigência de sinceridade. Agora, contudo, a capacidade de defender uma tese sem nela crer não é vista como algo negativo. Não mais se trata de acusar a presença de uma mentira ali onde se vê um mérito, o de saber falar e pensar ao modo do interlocutor, trazendo sua posição para um debate realmente filosófico.

$*$
$* \quad *$

O que tudo isso significa, na progressão do diálogo? Com a retomada da tese de Trasímaco por Glauco e Adimanto, foi possível, como vimos, purgá-la de sua passionalidade e, digamos assim, da ideologia que a conformava. Mas era preciso, antes de tudo, refutar Trasímaco, afastá-lo da tese defendida, para que essa mesma tese pudesse receber seu devido tratamento, um tratamento filosófico, que só se pode obter por uma defesa desapaixonada, como é a de Glauco e Adimanto, que não endossam a

2005, p. 25-6). L. Strauss observa que, com a entrada em cena dos dois irmãos, a discussão "muda profundamente seu caráter. Torna-se completamente ateniense...Eles preenchem num grau considerável as condições afirmadas por Aristóteles em sua Ética que os participantes nas discussões de nobres assuntos devem preencher...Eles pertencem, afinal, à timocracia, o regime dedicado à honra" (Op. cit., p. 85). Alguns intérpretes têm considerado que o discurso de Trasímaco, sobretudo os argumentos que apresenta durante seu debate com Sócrates, seriam deliberadamente confusos e desprovidos de unidade e coerência. É o que julga, por exemplo, $\mathrm{N}$. P. White, comentando a intervenção do sofista em 337d-339b: "A posição de Trasímaco é estruturada de uma forma algo confusa, sem dúvida refletindo a opinião de Platão de que os que sustentam tais posições, em geral, não as articulam muito bem. São-nos oferecidas três versões da posição que são intimamente relacionadas mas, no entanto, distintas. O fato de haver tantas posições defendidas por Trasímaco produz certa confusão no leitor...Mais uma vez, devemos lembrar que o propósito do livro I é levantar questões. O que Platão julga ser central em opiniões com as de Trasímaco é expresso a seguir com mais clareza no livro II, quando Glauco e Adimanto apresentam o que Platão considera o problema principal que Trasímaco estava tentando articular (358a-362c, 362d-368c)" (A Companion to Plato's Republic, Hackett, Indianapolis, 1979, p. 65). Não vamos aqui tentar decidir se Trasímaco é portador de uma posição consistente ou não, mas se realmente houver uma deliberada inconsistência em sua argumentação, parece-nos que ela deve realmente ser relacionada à sua visão de mundo, paradigmaticamente simbolizada em seu caráter selvagem e violento e na busca do predomínio de seus interesses. 
tese que formulam e defendem. Tal tese tem valor filosófico, mas esse valor só se deixa perceber se a abordamos da maneira correta - à maneira de Glauco e Adimanto ${ }^{24}$.

Em que consiste esse valor filosófico, para uma tese tão assustadora como a de nosso sofista? Voltemos a nosso ponto de partida: Glauco e Adimanto a formularam nos termos de uma teoria da natureza humana e suas decorrências para a lei, algo que Trasímaco parece não ter explicitado. Essa formulação, como vimos, proporciona a via para a construção da concepção de justiça da cidade ideal, construção que, como sabemos, encontra sua originalidade na conciliação que opera entre natureza e lei, pois se justo é que cada um faça na cidade o que deve fazer por natureza, era preciso inicialmente pôr nestes termos o tema e o desafio de Trasímaco - é o que fazem os dois irmãos. Ora, é preciso observar também que tal definição de justiça dada no livro IV não deixa de ser uma retomada, agora devidamente fundamentada, da definição, por assim dizer, de senso comum, apresentada por Polemarco antes da entrada em cena de Trasímaco: a justiça consiste em dar a cada um o que lhe é devido (331e e segs.). Nesse sentido, a definição de justiça na cidade construída por Sócrates, Glauco e Adimanto pode ser considerada como a boa formulação daquela definição, que Platão, então, pretendeu sempre manter no horizonte de sua investigação, para talvez dar a sua proposta alcance e força de persuasão ${ }^{25}$. Pois na cidade ideal cada um tem o que lhe é devido, com o acréscimo agora do comentário filosófico que explica que quem confere o que é devido é o filósofo, que governa legitimamente, e o que é devido se determina pela inclinação natural - o que explica o próprio governo do filósofo.

Por que, então, todo o episódio trasimaquiano? É que aquela definição comum, sabe-o muito bem Platão, pode também servir como ponto de partida para a tese de Trasímaco. Se definirmos a justiça como dar a cada um o que lhe é devido e interpretarmos essa proposição à maneira de Polemarco e de seu velho pai Céfalo, isto é, por um prisma estritamente individualista, arriscamo-nos a produzir uma perigosa lacuna na dimensão política da definição, lacuna essa que Trasímaco e seu profundo

\footnotetext{
${ }^{24}$ Para L Strauss, a tese de Trasímaco, em toda sua violência e selvageria, só poderia ser defendida com convicção por alguém que detém um perfil violento e selvagem. Trasímaco, sua tese e comportamento seriam, para ele, uma versão do "discurso injusto" que em As Nuvens Aristófanes faz vencer o "discurso justo". Cf. L. Strauss, op. cit., p. 74. Segundo I. H. Jang, a visão pragmática que Trasímaco tem do saber não lhe permite crer na possibilidade de um "amor desinteressado pela verdade", pelo qual os que a buscam pudessem cooperar mutuamente - cf. art. cit., p. 199).

${ }^{25}$ Sobre isso, cf. Kahn, art. cit., p. 137, para quem a definição de Polemarco é uma "aproximação parcial" da definição posterior.
} 
pragmatismo saberão ocupar, oferecendo uma definição que certamente encontra acolhida numa espécie de senso comum político, porque resultante de um cinismo realista que decerto fundamenta uma opinião corrente em certos meios influentes ${ }^{26}$.

A formulação de Glauco e Adimanto, portanto, não é neutra e também não é simples repetição da tese de Trasímaco: ela prepara o caminho para a boa forma de pensar o tema da justiça. Mas Trasímaco, então, teve importante papel no primeiro livro, porque trouxe a discussão sobre a justiça, de um nível, digamos, individual, para aquele que mais interessa, o da cidade. Ao fazê-lo, permitiu que a análise platônica se iniciasse pela visão comum, algo que sempre caracterizou diálogos de definição, para então elevar a investigação a um novo plano, agora não mais completamente equivalente ao anterior - e nesse sentido pode-se realmente afirmar que no primeiro livro Platão quis exibir os limites de um estilo "socrático" de investigação. Mas era preciso também refutar Trasímaco - isto é, desqualificar sua figura, separando o conteúdo de sua tese do fato de ter sido por ele formulada. Noutras palavras, o primeiro livro mais refuta Trasímaco do que sua tese, e a retomada por Glauco tem a função de formulá-la, agora, separada da mentalidade de seu defensor. A reformulação da tese a apresenta agora destacando o que nela está embutido de conteúdo filosófico: uma teoria da natureza humana.

Ao mesmo tempo, o fato de serem Glauco e Adimanto quem a reformulam, fazendo-o sem dar-lhe assentimento, mas apenas para fins de análise, dá testemunho da necessidade de afastar o elemento subjetivo e passional: a defesa de Trasímaco dessa tese, por causa de sua apaixonada e até violenta adesão, não permite a descoberta da boa via de sua investigação. Glauco e Adimanto, capazes que são de formulá-la adequadamente, sem, contudo, a ela aderir, prestam um inestimável serviço à démarche inquiridora do diálogo.

Há, portanto, um significado importante para a idéia de que o segundo livro de $A$ República contém uma mudança e até mesmo uma crítica ao estilo de investigação filosófica presente em diálogos anteriores, pois Glauco e Adimanto, com sua atitude filosófica, representam a introdução de uma novidade: não mais é possível o diálogo

\footnotetext{
${ }^{26}$ Sobre o sentido das definições de Céfalo e Polemarco, cf. Annas, op. cit., p. 20-1, 23-4, 27-8. "Polemarco representa o melhor que o senso comum tem a oferecer sobre a justiça" (p. 34). Quanto a Trasímaco, segundo Annas, sua posição, embora inicialmente se expresse à maneira de um "convencionalismo", seria, na verdade, uma forma de "imoralismo". Cf. p. 36-7.
} 
com qualquer interlocutor, como parece ter sido o caso naqueles diálogos. Agora, a investigação da verdade, o diálogo propriamente dito, exige interlocução adequada ${ }^{27}$.

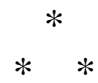

Todas essas análises sobre a retomada por Glauco e Adimanto, sobretudo a do primeiro, da tese de Trasímaco, além de nos instruírem sobre importantes características do que poderemos talvez chamar de platonismo maduro, nos levam a um outro tema de grande relevância, certamente menos valorizado do que o das relações entre discípulo e mestre, mas de significação inconteste. É que elas nos ajudam a compreender uma das principais características dos diálogos de Platão: o papel neles desempenhado pela construção de suas personagens. Embora a leitura dessas excepcionais construções indubitavelmente produza no leitor a impressão justa de estar em face de uma obra que porta ao mesmo tempo grande fôlego especulativo e inegável valor literário, devemos evitar a cômoda conclusão de que estamos aí em face de uma feliz coincidência. É preciso ir além disso e reconhecer que os diálogos só se compreendem plenamente se observamos a relevância filosófica de seu trabalho literário, isto é, se conseguimos divisar o alcance que essas meticulosas e sutis operações da escrita possuem para a compreensão das intenções filosóficas que os movem.

Vimos então que, mais do que expediente literário, as personagens de Glauco e Adimanto representam a presença necessária do filosofar no início do trajeto que conduz à boa doutrina da cidade ideal de A República. Mas, para isso, foi preciso descrevê-los e pintá-los de acordo com as características que esse mesmo diálogo e outros a ele próximos consideram filosóficas. É um conceito de filosofia e de filósofo o

${ }^{27}$ Isso não quer dizer que a presença de interlocutores dotados de um perfil filosófico semelhante seja sinal inequívoco de estatuto filosófico afirmativo. No Teeteto, por exemplo, encontramos um interlocutor portador de grande capacidade intelectual e atitude filosófica adequada, mas isso não garante a construção de um saber, pois o diálogo termina em aporia. A presença de tais interlocutores, apesar de ser talvez uma condição necessária, não é condição suficiente - embora talvez se possa argumentar que há um ganho filosófico significativo no Teeteto: a refutação de Protágoras. De qualquer modo, a questão é pertinente. Por outro lado, observem-se, a título de comparação, as personagens Símias e Cebes, do Fédão, que possuem algumas semelhanças com Glauco e Adimanto. Símias e Cebes são iniciados na filosofia pela via do pitagorismo de Filolau (61d). Cebes é descrito por Sócrates como alguém que não se convence facilmente (cf. 62e-63a), e Símias se mantém atento ao que pensariam os homens em geral das teses socráticas (cf. 64a-b). Ambos terão papel ativo na construção das provas da imortalidade da alma, apresentando objeções de relevância filosófica evidente. 
que norteia a construção dos dois personagens. O talento literário de Platão está, aqui, a serviço de seu talento filosófico.

Ora, se não nos damos conta desse casamento feliz, corremos o risco de perder de vista o quanto de mensagem filosófica se encontra nesse verdadeiro artesanato que Platão é capaz de exercitar em seus diálogos. Por exemplo: já se observou, com razão, que em A República os dois irmãos, que são também irmãos de Platão, são os “destinatários paradigmáticos do esforço reeducativo necessário à construção da cidade justa: trata-se de libertá-los do pensamento dos 'maus mestres' próprios de toda sua geração, para dotá-los de uma cultura em condições de completar sua boa predisposição natural, de impedir seu eventual desvio oligárquico e tirânico (exatamente como Crítias e Alcibíades) e transformá-los, ao contrário, nos construtores e defensores da nova cidade" $^{28}$. Os irmãos Glauco e Adimanto, como destinatários ideais, encontram nessa investigação sobre a justiça, na cidade e na alma, a oportunidade de conhecerem-se a si mesmos $^{29}$, e representam, portanto, também os leitores ideais de A República e talvez de grande parte dos diálogos de Platão. Esta, contudo, é outra questão, que deixamos aqui sugerida a seus leitores ${ }^{30}$.

Roberto Bolzani Filho Universidade de São Paulo

\footnotetext{
${ }^{28}$ Vegetti, op. cit., p. 153. Cf. também A. Bloom, The Republic of Plato, p. 339, embora afirme um apego dos irmãos a Trasímaco que soa demasiado. Cf. também J. Lear, art. cit., p. 36-7

${ }^{29}$ Cf. Bernadete, op. cit., p. 43.

${ }^{30}$ Agradeço a Maria Sylvia de Carvalho Franco, Paula da Cunha Corrêa, David Bouvier, Marcelo Pimenta Marques e principalmente a Marcelo Boeri pelas observações feitas durante e depois da apresentação de uma primeira e embrionária versão deste texto no "II Colóquio Platônico: Politeía, II', Itatiaia, Maio de 2006.
} 


\section{Bibliografia}

Annas, J. An Introduction to Plato's Republic, Oxford, Clarendon Press, 1981.

Bernadete, S. Socrates`Second Sailing - on Plato`s Republic, Univ. Chicago Press, 1989.

Bloom, A. The Republic of Plato, Basic Books, 1991.

Burnyeat, M. "Fathers and Sons in Plato's Republic and Philebus", Classical Quarterly 54.1, 2004, p. 80-87.

Ferrari, G. F. R. City and Soul in Plato's Republic, Univ. Chicago Press, 2005.

Jang, I. H. "Socrates Refutation of Thrasymachus", History of Political Thought, vol. XVIII, n. 2, 1997,.

Kahn, C. H. "Proleptic composition in the Republic, or why Book 1 was never a separate dialogue", Classical Quarterly 43 (i), 1993, p. 131-42.

Lear, J. "Allegory and Myth in Plato's Republic", Blackwell Guide to Plato's Republic, G. Santas (ed.), Blackwell, 2005.

Pappas, N. Plato and the Republic, Routledge, London, 1995.

Platão, República. Trad. Anna Lia Amaral de Almeida Prado, São Paulo, Martins Fontes, 2006.

Rowe, C. "The Literary and Philosophical Style of the Republic", The Blackwell Guide to Plato's Republic, G. Santas (ed.), Blackwell, 2006, p. 7-24.

Strauss, L. The City and Man, Univ. Chicago Press, 1978.

Vegetti, M. La Repubblica, vol. II, Libri II e III, Bibliopolis, 1998.

White, N. P. A Companion to Plato's Republic, Hackett, Indianapolis, 1979. 